\title{
ESTIMATION OF THE CHARGED DEFECT DENSITY FROM HOT- ELECTRON TRANSPORT STUDIES IN EPITAXIAL ZnO
}

\author{
L. Ardaravičius, O. Kiprijanovič, M. Ramonas, E. Šermukšnis, \\ A. Šimukovič, and A. Matulionis \\ Center for Physical Sciences and Technology, Sauletekio 3, 10257 Vilnius, Lithuania \\ Email: linas.ardaravicius@ftmc.lt
}

Received 20 May 2019; revised 11 July 2019; accepted 25 November 2019

\begin{abstract}
High-field electron transport measurements by applying short (few ns) voltage pulses on nominally undoped $\mathrm{n}$-type $\mathrm{Zn}$-polar $\mathrm{ZnO}$ epilayers are reported and interpreted in terms of the Boltzmann kinetic equation. The transient measurements do not demonstrate a significant change in the electron density up to $320 \mathrm{kV} / \mathrm{cm}$ electric field. This result together with the experimental data on the current allows one to estimate the electron drift velocity from the measured current: the highest value of $\sim 2.9 \times 10^{7} \mathrm{~cm} / \mathrm{s}$ is obtained at the pre-breakdown field of $320 \mathrm{kV} / \mathrm{cm}$ for the $\mathrm{ZnO}$ layer with the electron density of $1.5 \times 10^{17} \mathrm{~cm}^{-3}$. The densities of double-charged oxygen vacancies $\left(\sim 1.6 \times 10^{17} \mathrm{~cm}^{-3}\right)$ and other charged centres $\left(\sim 1.7 \times 10^{17} \mathrm{~cm}^{-3}\right)$ are assumed for the best fit of the simulated and measured hot-electron effect. A correlation with the epilayer growth conditions is demonstrated: the higher $\mathrm{Zn}$ cell temperature favours the formation of a higher density of the oxygen vacancies $\left(1.9 \times 10^{17} \mathrm{~cm}^{-3}\right.$ at $\left.347^{\circ} \mathrm{C}\right)$.
\end{abstract}

Keywords: $\mathrm{ZnO}$ epilayer, charged defects, differential mobility, electron drift velocity, high electric fields

\section{Introduction}

Zinc oxide $(\mathrm{ZnO})$ is a transparent semiconductor with a direct and relatively wide bandgap [1-3]. Its superiority in temperature resistance and high electron saturation velocity [4] is also promising to thin film transistors for high-temperature and high-power operations [5-7]. Many properties of $\mathrm{ZnO}$ are similar to those of GaN. Particular advantages of $\mathrm{ZnO}$ over $\mathrm{GaN}$ include higher electron drift velocity and breakdown field [8], bulk growth capability, amenability to conventional chemical etching, low growth temperature, high radiation hardness and large exciton binding energy [9-13]. The epitaxial technology of $\mathrm{ZnO}$ is less expensive, albeit relatively not so well developed compared to that of GaN.

The electron low-field mobility in $\mathrm{ZnO}$ is mainly determined by scattering on charged defects.
There is an experimental evidence that doublecharged oxygen vacancies act as shallow donors and charged scattering centres [14]. The oxygen vacancies were studied by an electrochemical method [15], optical absorption [16], optically detected electron paramagnetic resonance [17], positron annihilation spectroscopy [18], or after studying oxygen self-diffusion in oxygen-isotope $\mathrm{ZnO}$ [14]. The density-functional theory calculations were also applied to study oxygen vacancies [19]. The typical density of the vacancies exceeded $10^{17} \mathrm{~cm}^{-3}[15,16,18$. The highest electron lowfield mobility around $400 \mathrm{~cm}^{2} /(\mathrm{Vs})$ was reported at room temperature in epitaxial $\mathrm{ZnO}$ layers with low residual impurity densities [20]. Polar scattering by longitudinal optical (LO) phonons was found important at low and moderate electron densities [21]. The room temperature electron mobility $\left(430 \mathrm{~cm}^{2} /(\mathrm{V} \mathrm{s})\right)$ calculated for the electron 
and donor densities of $10^{17} \mathrm{~cm}^{-3}$ [22] slightly exceeded the maximum measured value.

The results of Monte Carlo simulations [ 4,8 , 23, 24 were used for the interpretation of the experimental studies [25-27] of high-field electron transport in epitaxial $\mathrm{ZnO}$ channels. The dependence of electron drift velocity on the electron density was deduced at room temperature for doped $\mathrm{ZnO}$ [26]. High electric fields $(430 \mathrm{kV} / \mathrm{cm})$ and velocities $\left(\sim 2.7 \times 10^{7} \mathrm{~cm} / \mathrm{s}\right.$ at $\left.320 \mathrm{kV} / \mathrm{cm}\right)$ were reported for nominally undoped $\mathrm{ZnO}$ epilayers at room temperature [27].

The goal of this paper is to examine the electron scattering by charged defects through the study of hot-electron effects in nominally undoped $\mathrm{ZnO}$ epilayers at room temperature. The current-voltage dependence is measured up to high electric fields, and the experimental results are fitted with the solution of the Boltzmann kinetic equation. The results are used for the estimation of electron density, drift velocity and low-field mobility. The electron scattering by the double-charged oxygen vacancies and other charged defects is discussed.

\section{Theoretical background}

The Boltzmann kinetic equation is used for the investigation of electron scattering and hot-electron transport in nominally undoped $\mathrm{ZnO}$. The highlyefficient spherical harmonics approach [28] is employed for the calculation of the differential mobility deduced from a small-signal response at $1 \mathrm{GHz}$ at a constant applied electric field. The calculations are performed for the nonparabolic $\Gamma_{1}$ valley with the electron effective mass of $0.21 \mathrm{~m}_{\mathrm{e}}$ and the non-parabolicity coefficient of $0.4 \mathrm{eV}$ [23]. More details on the model are available elsewhere [22, 27]. Eight spherical harmonics are found sufficient for an accurate enough approximation of the electron distribution function. The change in calculation results is negligible if higher spherical harmonics are included.

The electron scattering on acoustic phonons, longitudinal optical phonons and screened point defects is taken into account. Deformation-potential and piezoelectric mechanisms are considered for the acoustic phonon scattering. The Fröhlich approximation is used for interaction with the optical phonons. Charged defects are treated in the screened Coulomb potential approach within the Brooks and Herring model for point scattering centres. The electron gas degeneracy is not included in the present calculations. The electron density is considered lower than the total ionized centre density because of the known compensation of the shallow donors by other charged defects acting as acceptors. The total effective density of the charged defects is introduced as follows:

$$
N_{\text {eff }}=\sum N_{i} Z_{i}^{2}
$$

Here the defect density $N_{i}$ of an $i$ th type is weighted by the number $Z_{i}$ of elementary charges on

a single defect of the ith type.
The differential mobility $\mu(E)=\frac{\mathrm{d} v_{\mathrm{d}}}{\mathrm{d} E}$ is deduced from the small-signal response at $1 \mathrm{GHz}$, and the results are illustrated in Fig. 1 as a function of the applied electric field. The curves stand for different values of the effective defect density $N_{\text {eff }}$ The density of the hot-electron gas is kept constant at $1.8 \times 10^{17} \mathrm{~cm}^{-3}$. The mobility decreases as the electric field increases. The curves merge at electric fields over $100 \mathrm{kV} / \mathrm{cm}$, and the value becomes almost independent of the defect scattering. The calculations are terminated at

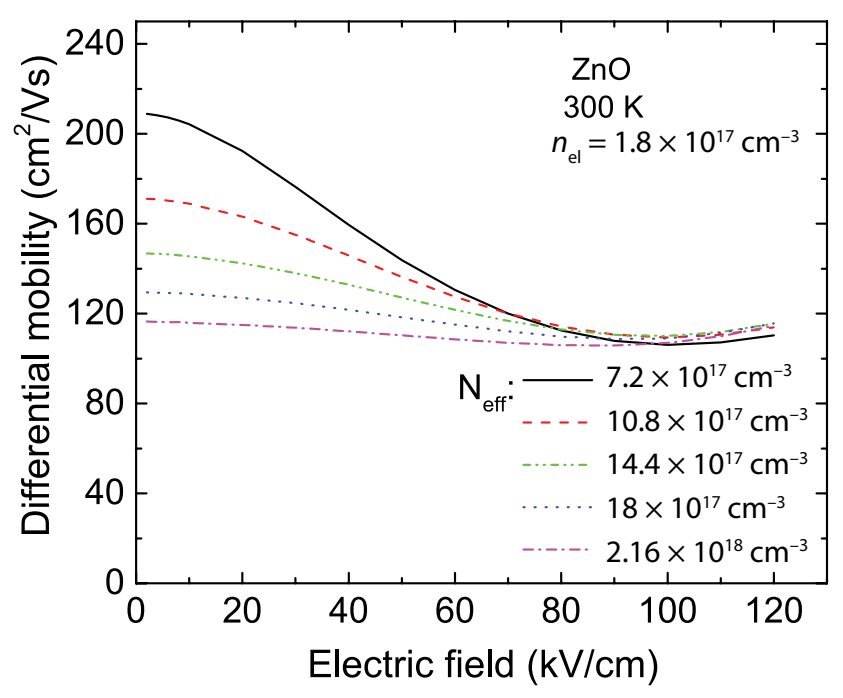

Fig. 1. Dependence of the calculated differential electron mobility (small-signal response at $1 \mathrm{GHz}$ ) on the applied electric field for $\mathrm{ZnO}$ at room temperature. Curves stand for different effective density of charged defects, $N_{\text {eff }}: 7.2 \times 10^{17} \mathrm{~cm}^{-3}$ (solid line), $10.8 \times 10^{17} \mathrm{~cm}^{-3}$ (dashed line), $14.4 \times 10^{17} \mathrm{~cm}^{-3}$ (dashdot-dots), $18 \times 10^{17} \mathrm{~cm}^{-3}$ (dots), $2.16 \times 10^{18} \mathrm{~cm}^{-3}$ (dash-dots). The electron density is $1.8 \times 10^{17} \mathrm{~cm}^{-3}$. 
$E=120 \mathrm{kV} / \mathrm{cm}$ because electron runaway develops at higher fields unless the upper valleys are taken into account. The values of the differential mobility at low and moderate electric fields are compared in Fig. 2 .

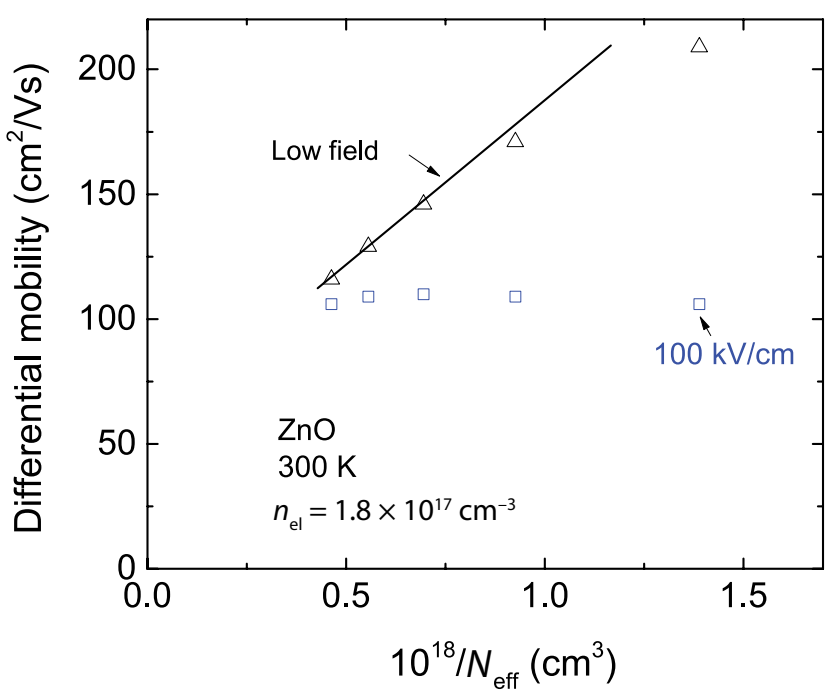

Fig. 2. Calculated differential mobility as a function of the reciprocal effective density, $1 / N_{\text {eff }}$ at a low-electric field $E=2 \mathrm{kV} / \mathrm{cm}$ (triangles) and at $E=100 \mathrm{kV} / \mathrm{cm}$ (squares) for $\mathrm{ZnO}$ at room temperature. The electron density $n_{\mathrm{el}}=1.8 \times 10^{17} \mathrm{~cm}^{-3}$.

An almost linear dependence of the mobility on $N_{\text {eff }}{ }^{-1}$ at low fields (Fig. 2, triangles) shows that the defect scattering plays the dominant role. The deviation from the linear dependence (triangles and line) illustrates a weak contribution of the phonon scattering. This is a strong argument that the low-field mobility is controlled by the ionized defect scattering.

On the other hand, the longitudinal optical phonon scattering becomes important at high electric fields. According to calculations, the hot-electron differential mobility is almost independent of the defect scattering (Fig. 2, squares). This conclusion is in contrast to the known behaviour of the hot-electron drift velocity: the ionized donor scattering reduces the drift velocity considerably at any fixed electric field (except for the extremely high ones) [22, 24].

Consequently, the value of the differential mobility at high fields can be used as a reference for the estimation of the electron density and the drift velocity if the differential conductivity is available from the experiment. Indeed, the differential conductivity of hot electrons at moderate fields $\left(E=E_{\mathrm{m}}\right)$ is

$$
\sigma\left(E_{\mathrm{m}}\right)=e n\left(E_{\mathrm{m}}\right) \mu\left(E_{\mathrm{m}}\right),
$$

where $\mu\left(E_{\mathrm{m}}\right)$ is the differential mobility at $E=E_{\mathrm{m}}$ and $\sigma\left(E_{m}\right)=\frac{\mathrm{dj}}{\mathrm{d} E}$ is the differential conductivity measured as the slope of the current densityfield $j(E)$ dependence at $E=E_{\mathrm{m}}$. From this equation the electron density $n\left(E_{\mathrm{m}}\right)$ can be estimated. Once the electron density is known, the electron drift velocity can be estimated from the measured current density. For demonstration of these possibilities on $\mathrm{ZnO}$ epilayers, the hot-electron transport experiment is carried out.

\section{Samples}

The investigated $\mathrm{ZnO}$ epilayers were grown by plasma-assisted molecular beam epitaxy (PA-MBE) at Virginia Commonwealth University (USA). Highly-resistive $(60 \mathrm{k} \Omega \mathrm{mm})$, carboncompensated $2.5 \mu \mathrm{m}$ Ga-polar (0001) GaN layers, prepared by metal-organic chemical vapour deposition on $c$-plane sapphire, served as substrates. Two $\mathrm{Zn}$-polar $\mathrm{ZnO}$ structures included into this study were grown at $670^{\circ} \mathrm{C}$ with two different $\mathrm{Zn}$ cell temperatures employed for the growth (340 and $347^{\circ} \mathrm{C}$ for the growth of the $\# 1153$ and $\# 1161$ structures, respectively). Other parameters used for depositing a low-temperature (LT) nucleation layer at $300^{\circ} \mathrm{C}$ as well as the oxygen gas flow rate $(1.6 \mathrm{sccm})$ and plasma power $(400 \mathrm{~W})$ used for the growth at $670^{\circ} \mathrm{C}$ were identical. The resultant growth rates were $115 \mathrm{~nm} / \mathrm{h}$ for \#1153 and $135 \mathrm{~nm} / \mathrm{h}$ for \#1161. More oxygen-rich conditions (\#1153) as well as lower substrate temperature caused a lower point defect density (either oxygen vacancies or $\mathrm{Zn}$ interstitials) and gave rise to lower electron density.

The transmission line measurement (TLM) patterns were processed with evaporated $\mathrm{Ti} / \mathrm{Au}$ $(25 \mathrm{~nm} / 30 \mathrm{~nm})$ stacks acting as ohmic contacts. The channel width $w$ was $300 \mu \mathrm{m}$, the thicknesses were 350 and $375 \mathrm{~nm}$ for \#1153 and \#1161, respectively, and the interelectrode distances $L$ were $1.7,3.9$, and 6.9, 9.9 and $15.8 \mu \mathrm{m}$. The contact resistance was estimated at low electric fields from the dependence of the sample resistance on the interelectrode distance. The channel resistance, the length and the cross section area were used to estimate the low-field conductivity $\sigma_{0}$ (Table 1 ). 
Table 1. Zn cell temperature, ohmic contact resistance, epilayer low-field conductivity, electron low-field drift mobility, electron density, oxygen vacancy density, and other charged centre (dangling bonds) density for the investigated $\mathrm{ZnO}$ epilayers at room temperature.

\begin{tabular}{ccc}
\hline Wafer & $\# 1153$ & $\# 1161$ \\
\hline Zn cell temperature & $340^{\circ} \mathrm{C}$ & $347^{\circ} \mathrm{C}$ \\
\hline Contact resistance & $23 \pm 10 \Omega$ & $22 \pm 7 \Omega$ \\
\hline Epilayer conductivity $\sigma_{0}$ & $4.7 \pm 0.9 \mathrm{~S} / \mathrm{cm}$ & $5.5 \pm 1.1 \mathrm{~S} / \mathrm{cm}$ \\
\hline Electron drift mobility $\mu_{0}$ & $195 \pm 39 \mathrm{~cm}^{2} / \mathrm{V} \mathrm{s}$ & $178 \pm 36 \mathrm{~cm}^{2} / \mathrm{V} \mathrm{s}$ \\
\hline Electron density $n_{0}$ & $1.5 \pm 0.3 \times 10^{17} \mathrm{~cm}^{-3}$ & $1.9 \pm 0.4 \times 10^{17} \mathrm{~cm}^{-3}$ \\
\hline Oxygen vacancy density $N_{+}$ & $1.6 \pm 0.3 \times 10^{17} \mathrm{~cm}^{-3}$ & $1.9 \pm 0.4 \times 10^{17} \mathrm{~cm}^{-3}$ \\
\hline Other charged centre density $N_{-}$ & $1.7 \pm 0.3 \times 10^{17} \mathrm{~cm}^{-3}$ & $2.0 \pm 0.4 \times 10^{17} \mathrm{~cm}^{-3}$ \\
\hline
\end{tabular}

The electron mobility available from the Hall effect measured in the van der Pauw configuration was substantially lower than that obtained from the magnetoresistance measurements carried out on the TLM samples [27], and a new method based on the hot-electron effect was developed for the electron density and the low-field mobility. This enabled the estimation of the oxygen vacancy and other charged centre densities.

\section{Experiment}

Electron transport measurements at high electric fields were carried out on the two-electrode samples selected from the TLM patterns. The measurement procedure and the determination of current-voltage $(I-U)$ dependence is described in Refs. [29, 30]. The data for evaluating the current and the voltage drop along the channel were obtained from the oscilloscope amplitudes when either a reference cable or the sample under test was present in the circuit. The employment of nanosecond pulses allowed us to minimize the channel self-heating due to current [31]. The average electric field was estimated as $E=(U-I R) / L$. Figure 3 presents the dependence of the current on the voltage pulse width for the $\mathrm{ZnO}$ samples: the highest current values are attained with the shortest pulse duration ( $3 \mathrm{~ns}$ ).

The transient studies are carried out with short pulses of voltage. The current $I(t)$ and the voltage $U(t)$ are obtained from the waveforms of the transmitted and reference signals. The current deduced during the rise edge nearly coincides with that available from the falling edge. This indicates that the electron density remains constant in the electric field range up to $320 \mathrm{kV} / \mathrm{cm}$ [27].

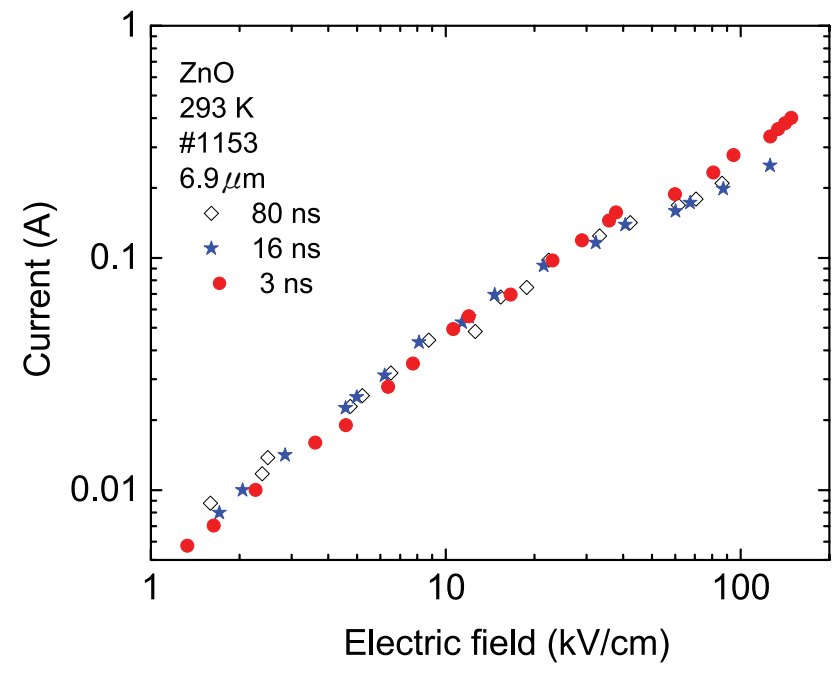

Fig. 3. Room-temperature current-field dependence for the $\mathrm{ZnO}$ sample \#1153. Voltage pulse duration is 3, 16 and $80 \mathrm{~ns}$. Interelectrodal distance is $6.9 \mu \mathrm{m}$. Contact resistance is $33 \Omega$.

The coincidence suggests that neither the sample temperature nor the electron density change with time and field, i.e. $n_{0}=n\left(E_{m}\right)$, where $n_{0}$ is electron density at low electric fields. In other words, the sample self-heating as well as possible excess generation of electrons by the electric field, the hotelectron capture and the thermal release do not play an important role within the time domain of the short pulse of voltage. This is a good base for the interpretation of the experimental results on the current in terms of the electron scattering.

The electron drift velocity $v_{\mathrm{dr}}(E)$ was estimated from the current $I$ measured in the direction perpendicular to the $\mathrm{c}$ axis of $\mathrm{ZnO}$ according to the expression

$$
v_{\mathrm{dr}}(E)=\frac{I(E)}{e n_{0} S},
$$


valid for the uniform electric field $E$ and the field-independent electron density $n_{0}$ (here $e$ is the elementary charge, $S=w d$ is the channel cross-section area).

Some samples suffered from soft damage at high electric fields. The damage was characterized by the change of the zero-field channel resistance measured before and after the high-field experiment. We present results up to a damage level not exceeding 5\%. The threshold field for soft damage can be introduced, as reported previously [30].

\section{Experimental results}

Figure 4 presents the transmitted current (a) and electric field (b) waveforms for the $\mathrm{ZnO}$ sample \#1161. The highest current of $0.8 \mathrm{~A}$ corresponds to $320 \mathrm{kV} / \mathrm{cm}$ peak field at $26 \mathrm{~dB}$ attenuation. Further, the voltage pulse length and the interelectrode distance were varied in order to find out the optimal conditions for resolving the effect of scattering on the hot-electron transport.

Figure 5(a) presents the relatively long voltage pulse (100 ns) measurements of the current on the average electric field for the sample \#1153. An essential deviation from the ohmic behaviour appears at average electric fields exceeding $10 \mathrm{kV} / \mathrm{cm}$ in long channels ( $L=15.8 \mu \mathrm{m}$, stars). Moreover, the deviation is sensitive to the channel length - it is weaker in shorter channels. In particular, the results for $1.7 \mu \mathrm{m}$ samples (squares) and those for $3.9 \mu \mathrm{m}$ (bullets) nearly match (within experimental error) at electric fields below $50 \mathrm{kV} / \mathrm{cm}$. The enhanced non-ohmic behaviour in the longchannel samples might be an indication of either enhanced scattering or reduced electron density due to sample self-heating and hot-electron trapping, respectively.

The use of short nanosecond voltage pulses ( $3 \mathrm{~ns}$ ) enabled us to reach the highest electric field of $430 \pm 50 \mathrm{kV} / \mathrm{cm}$ (Fig. 5(b), squares; the error is due to different contact resistance) for the $1.7 \mu \mathrm{m}$ long channel and attain the maximum current density of $1.15 \mathrm{~A}$ for the $L=6.9 \mu \mathrm{m}$ sample \#1161 (Fig. 5(b), triangles). Both current values are close to each other (triangles and diamonds) up to $230 \mathrm{kV} / \mathrm{cm}$ indicating that other effects are ruled out except for the hot-electron effect on the mobility. No soft damage was found for the channels \#1161, and the highest applied field was limited by the setup. When the field exceeded a certain value, $\sim 350 \mathrm{kV} / \mathrm{cm}$ for the $6.9 \mu \mathrm{m}$ channel (Fig. 5(b), triangles), the slope of $I-E$ dependence started increasing. Moreover, the shape of the current pulse did not follow the shape of the voltage pulse. In particular, for the $3.9 \mu \mathrm{m}$ channel (Fig. 5(b), diamonds), the current increased when the voltage decreased at the end of the pulse. These distortions in the pulse shape might be attributed to the increased electron density caused either by the impact ionization or de-trapping effects.
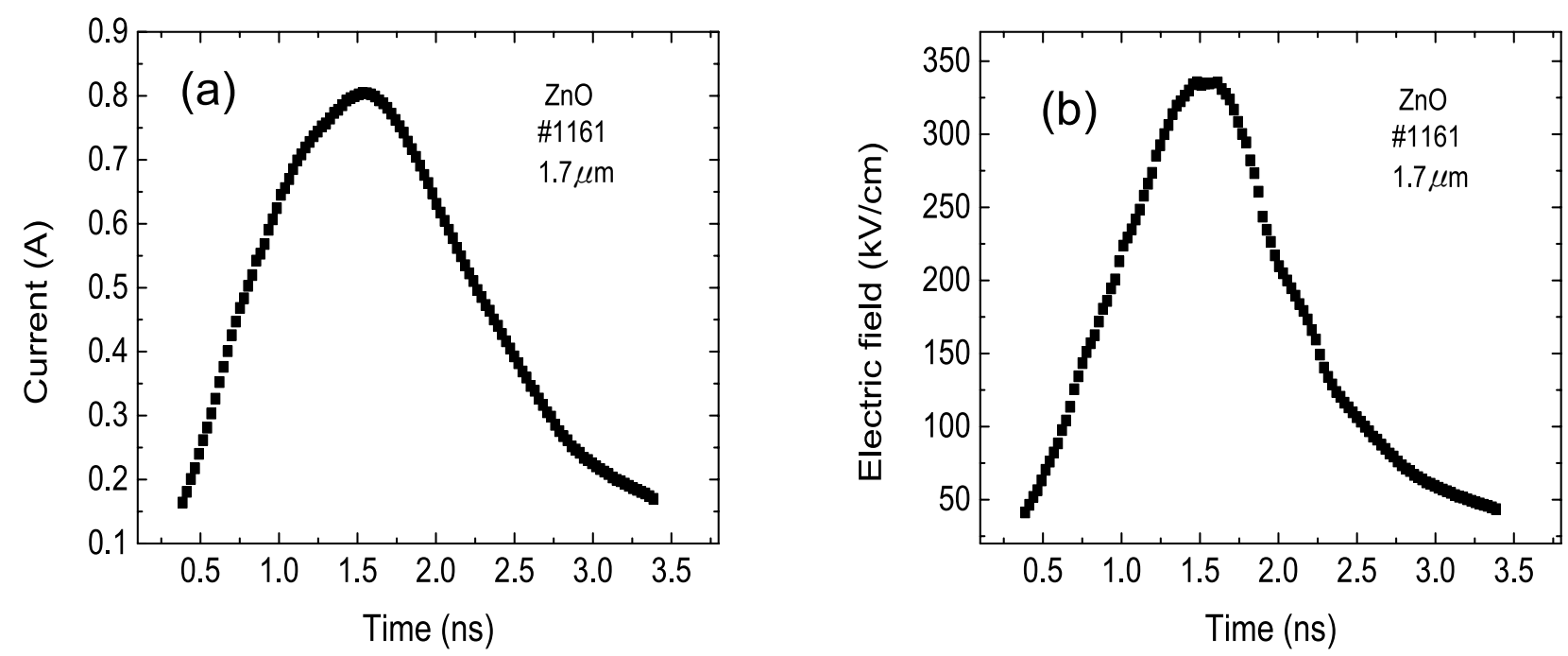

Fig. 4. Room-temperature current (a) and electric field (b) waveforms for the epitaxial $\mathrm{ZnO}$ measured in the transient mode. The interelectrode distance is $1.7 \mu \mathrm{m}$. The contact resistance is $25 \Omega$. The pulse halfwidth is 2 ns. 

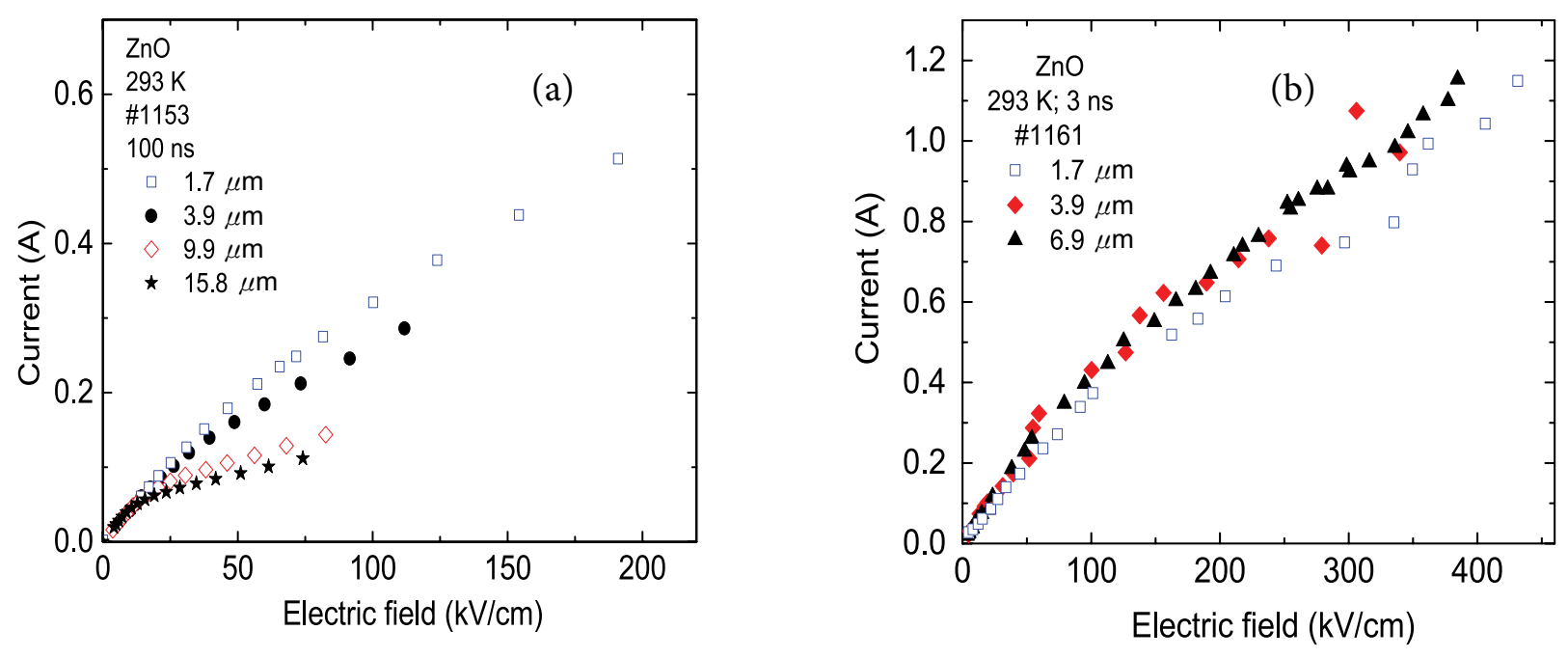

Fig. 5. The room-temperature current-field dependence for $\mathrm{ZnO}$ samples. (a) \#1153: the voltage pulse duration is $100 \mathrm{~ns}$ and the interelectrodal distance is 1.7 (squares), 3.9 (circles), 9.9 (diamonds) and $15.8 \mu \mathrm{m}$ (stars); (b) \#1161: the voltage pulse duration is $3 \mathrm{~ns}$ and the interelectrodal distance is 1.7 (squares), 3.9 (diamonds) and $6.9 \mu \mathrm{m}$ (triangles). The contact resistance is $25 \Omega$ for the used TLM pattern in \#1153 and 25, 27 and $18 \Omega$ for \#1161, respectively.

\section{Discussion}

The n-type conductivity of nominally undoped $\mathrm{ZnO}$ epilayers can be caused by oxygen vacancies [14, 17]. The redundant $\mathrm{Zn}$ atom gives its two electrons to the conduction band, and the oxygen vacancy becomes positively charged. One can estimate the density of vacancies by measuring the density of electrons in the conduction band. However, part of free electrons is captured by other charged centres (e.g. dangling bonds, impurities, and other point centres) present in epitaxial $\mathrm{ZnO}$ layers. Thus, the real density of electrons is always lower than the double density of vacancies.

We estimated the density of vacancies with the aid of electron scattering on them. Let us define the double charged density of vacancies as $N_{+}$ Also, $N_{-}$is the density of other charged defects, each capturing an electron. At the equilibrium, we have

$$
N_{+} Z_{+}=N_{-} Z_{-}+n_{0}
$$

where $Z_{+}=2$ is the number of elementary charges per vacancy and $Z_{-}=1$ defines the negative charge of a dangling bond with one electron. The charged defects scatter electrons. In the point scattering centre approximation, the scattering is propor- tional to the density of point defects multiplied by the squared number of elementary charges of the defect. Thus, after Eq. (1), the total scattering is proportional to the sum of contributions due to positively charged vacancies plus $Z_{-}^{2}$ times the negatively charged defects:

$$
N_{\text {eff }}=N_{+} Z_{+}^{2}+N_{-} Z_{-}^{2}
$$

One can approximate the results of current density on electric field (Fig. 6 of this work or Fig. 5 in [27]) with lines. For the sample \#1153, the Ohm's law is valid at low electric field (solid line), while the dominant scattering mechanism is due to optical phonons at moderate fields $\left(50<E_{\mathrm{m}}<250 \mathrm{kV} / \mathrm{cm}\right)$, and the so-called second Ohm's law is valid (Fig. 5, dashed line [27]). The differential conductivity estimated at moderate fields in \#1153 from the slope of the dashed line is $\sigma\left(E_{\mathrm{m}}\right)=2.55 \mathrm{~S} / \mathrm{cm}$. The ratio $\sigma_{0} / \sigma\left(E_{\mathrm{m}}\right)=1.84$. When the current is measured with the aid of nanosecond voltage pulses, the density of electrons does not depend on the electric field in the investigated samples, and we have $\sigma\left(E_{\mathrm{m}}\right) / \sigma_{0}=\mu\left(E_{\mathrm{m}}\right) / \mu_{0}$.

We estimated the ratio of the mobility at the low field, $\mu_{0}$, and the differential mobility at the moderate field, $\mu\left(E_{\mathrm{m}}\right)$, by solving of the Boltzmann kinetic equation through the spherical 


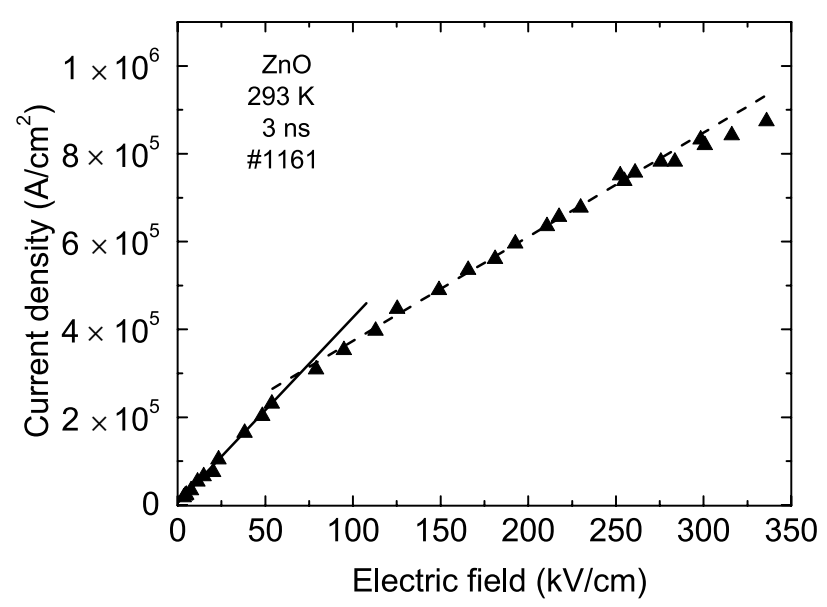

Fig. 6. The current density dependence on the electric field for the $\mathrm{ZnO}$ sample \#1161 at room temperature (triangles). A solid line stands for the Ohm's law. A dashed line with a lower slope illustrates the second Ohm's law. The voltage pulse duration is $3 \mathrm{~ns}$. The inter-electrode distance is $6.9 \mu \mathrm{m}$. The contact resistance is $18 \Omega$ (triangles).

harmonics expansion method. The dependence of the calculated ratio on the sum $N_{\text {eff }}$ (see Eq. (5)) is illustrated in Fig. ㄱ.

The electron degeneracy is insignificant in the nominally undoped $\mathrm{ZnO}$, and it is useful to consider the results when the electron density is constant with varying $N_{\text {eff }}$ Once the ra-

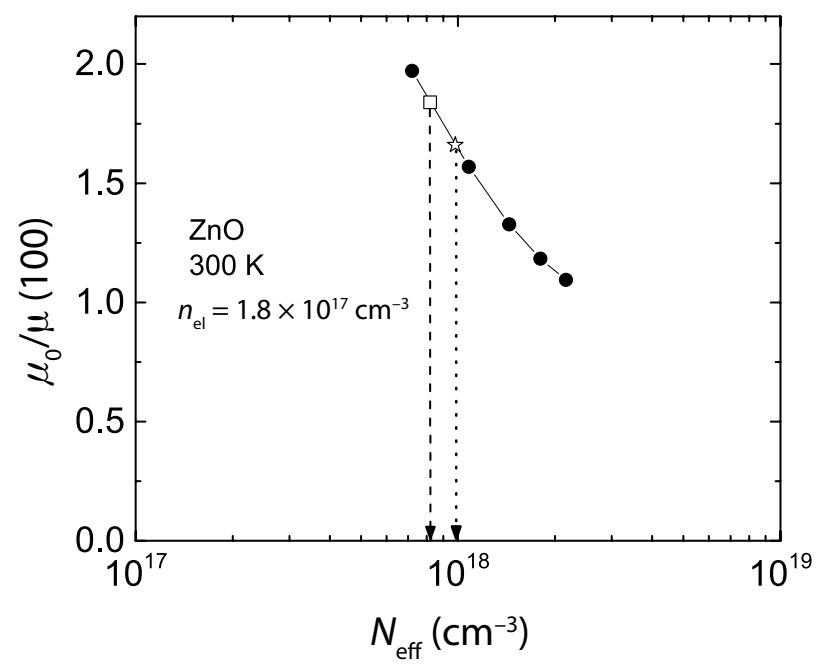

Fig. 7. The ratio of the calculated differential mobilities at low-electric field of 2 and $100 \mathrm{kV} / \mathrm{cm}$ (solid line, circles) versus the intensity of the defect scattering, $N_{\text {effr }}$ for the $\mathrm{ZnO}$ model at room temperature. The electron density in the simulation $n_{\mathrm{el}}=1.8 \times 10^{17} \mathrm{~cm}^{-3}$. The square and the star stand for the experimental values of the conductivity ratio for the samples \#1153 and \#1161, respectively. tio $\sigma\left(E_{\mathrm{m}}\right) / \sigma_{0}=\mu\left(E_{\mathrm{m}}\right) / \mu_{0}$ is valid, the square and the arrow for the sample \#1153 leads in Fig. 7 to $N_{\text {eff }}=8.2 \times 10^{17} \mathrm{~cm}^{-3}$. Knowing $N_{\text {eff }}$, we estimate the low-field mobility $\mu_{0}=195 \mathrm{~cm}^{2} /(\mathrm{V} \mathrm{s})$ from Fig. 2 and find the electron density $n\left(E_{\mathrm{m}}\right)=\sigma\left(E_{\mathrm{m}}\right) /$ $\left(e \mu\left(E_{\mathrm{m}}\right)\right)=n_{0}=\sigma_{0} /\left(e \mu_{0}\right)=1.5 \times 10^{17} \mathrm{~cm}^{-3}$. This electron density value is consistent with the magneto-resistance measurement results. Then we put $N_{\text {eff }}=8.2 \times 10^{17} \mathrm{~cm}^{-3}$ and $n_{0}=1.5 \times 10^{17} \mathrm{~cm}^{-3}$ values into Eqs. (4) and (5) and find the results for the \#1153 sample (Table 1). The oxygen vacancy density is estimated as $N_{+}=1.6 \times 10^{17} \mathrm{~cm}^{-3}$ and the density of other charged defects is found as $N_{-}=1.7 \times 10^{17} \mathrm{~cm}^{-3}$. These numbers are in fair agreement with the findings by other methods [18].

The same procedure is performed for the \#1161 sample (Table 1) which was grown under higher $\mathrm{Zn}$ cell temperature $\left(347^{\circ} \mathrm{C}\right)$. The higher $\mathrm{Zn}$ cell temperature favours the formation of higher density oxygen vacancies $\left(1.9 \times 10^{17} \mathrm{~cm}^{-3}\right)$, as shown in Table 1 .

Once the electron density is known, the electron drift velocity can be estimated from the measured current density $j=I / S$ and the estimated electron density according to Eq. (3). The highest experimental value for the electron drift velocity of $\sim 2.9 \times 10^{7} \mathrm{~cm} / \mathrm{s}\left(\sim 2.7 \times 10^{7} \mathrm{~cm} / \mathrm{s}\right)$ is found at $320 \mathrm{kV} /$ $\mathrm{cm}$ in the sample \#1153 (\#1161) with the electron density of $1.5 \times 10^{17} \mathrm{~cm}^{-3}\left(1.9 \times 10^{17} \mathrm{~cm}^{-3}\right)$.

A correlation with the growth conditions is resolved: a slightly higher drift velocity is estimated for the sample \#1153 with a lower density of oxygen vacancies. This wafer has been grown at lower $\mathrm{Zn}$ cell temperature (Table 1).

The contact resistance plays a role in the determination of the applied electric field in the $\mathrm{ZnO}$ channel. For example, the error of $14 \Omega$ in the ohmic contact resistance for the sample \#1161 shifts the highest electric from $320 \mathrm{kV} / \mathrm{cm}\left(R_{\mathrm{c}}=15 \Omega\right)$ to $300 \mathrm{kV} / \mathrm{cm}\left(R_{\mathrm{c}}=29 \Omega\right)$.

\section{Conclusions}

The nanosecond pulsed technique is used to single out the hot-electron transport and scattering in the nominally undoped $\mathrm{ZnO}$ epilayers at room temperature. The Boltzmann kinetic equation is solved within the spherical harmonics expansion method for considering the effect of electron scattering. The approach is proposed for 
estimating the density of oxygen vacancies (1.6$\left.1.9 \times 10^{17} \mathrm{~cm}^{-3}\right)$ and that of other single-charged defects $\left(1.7-2.0 \times 10^{17} \mathrm{~cm}^{-3}\right)$. The estimated density of the oxygen vacancies correlates with the $\mathrm{Zn}$ cell temperature.

The epilayers with the shortest inter-electrode distances withstand average electric fields up to $430 \pm 50 \mathrm{kV} / \mathrm{cm}$. Two ranges of electric field are resolved. The results on the non-ohmic transport are interpreted in terms of scattering by charged point defects and phonons: the electron drift velocity reaches the highest value of $\sim 2.9 \times 10^{7} \mathrm{~cm} / \mathrm{s}$ at $320 \mathrm{kV} / \mathrm{cm}$ electric field when the electron density is $1.5 \times 10^{17} \mathrm{~cm}^{-3}$.

\section{Acknowledgements}

This research was funded by the Research Council of Lithuania (Grant No. APP-5/2016). The authors are also grateful to the VCU Microelectronics Materials and Device Laboratory for the $\mathrm{ZnO}$ samples.

\section{References}

[1] D.C. Look, Progress in $\mathrm{ZnO}$ materials and devices, J. Electron. Mater. 35, 1299 (2006).

[2] C. Klingshirn, ZnO: From basics towards applications, Phys. Status Solidi B 244, 3027 (2007).

[3] GaN and ZnO-based Materials and Devices, ed. S. Pearton (Springer-Verlag, Berlin, 2012).

[4] J.D. Albrecht, P.P. Ruden, S. Limpijumnong, W.R.L. Lambrecht, and K.F. Brennan, High field electron transport properties of bulk $\mathrm{ZnO}$, J. Appl. Phys. 86, 6864 (1999).

[5] K. Koike, I. Nakashima, K. Hashimoto, S. Sasa, $M$. Inoue, and $M$. Yano, Characteristics of a $\mathrm{Zn}_{0.7} \mathrm{Mg}_{0.3} \mathrm{O} / \mathrm{ZnO}$ heterostructure field-effect transistor grown on sapphire substrate by molecular-beam epitaxy, Appl. Phys. Lett. 87, 112106 (2005).

[6] B. Bayraktaroglu, K. Leedy, and R. Neidhard, High-frequency $\mathrm{ZnO}$ thin-film transistors on $\mathrm{Si}$ substrates, IEEE Electron Device Lett. 30, 946 (2009).

[7] H. Morkoç and Ü. Özgür, Zinc Oxide: Fundamentals, Materials and Device Technology (WileyVCH, Weinheim, 2009).
[8] S.K. O'Leary, B.E. Foutz, M.S. Shur, and L.F. Eastman, Steady-state and transient electron transport within bulk wurtzite zinc oxide, Solid State Commun. 150, 2182 (2010).

[9] E. Ohshima, H. Ogino, I. Niikura, K. Maeda, M. Sato, M. Ito, and T. Fukuda, Growth of the 2-in-size bulk $\mathrm{ZnO}$ single crystals by the hydrothermal method, J. Cryst. Growth 260, 166 (2004).

[10]Y. Li, G.S. Tompa, S. Liang, C. Gorla, Y. Lu, and J. Doyle, Transparent and conductive Ga-doped $\mathrm{ZnO}$ films grown by low pressure metal organic chemical vapor deposition, J. Vac. Sci. Technol. A 15, 1063 (1997).

[11]W. Yang, R.D. Vispute, S. Choopun, R.P. Sharma, T. Venkatesan, and H. Shen, Ultraviolet photoconductive detector based on epitaxial $\mathrm{Mg}_{0.34} \mathrm{Zn}_{0.66} \mathrm{O}$ thin films, Appl. Phys. Lett. 78, 2787 (2001).

[12]S.O. Kucheyev, C. Jagadish, J.S. Williams, P.N.K. Deenapanray, M. Yano, K. Koike, S. Sasa, M. Inoue, and K. Ogata, Implant isolation of ZnO, J. Appl. Phys. 93, 2972 (2003).

[13]D.G. Thomas, The exciton spectrum of zinc oxide, J. Phys. Chem. Solids 15, 86 (1960).

[14]L. Liu, Z. Mei, A. Tang, A. Azarov, A. Kuznetsov, Q.-K. Xue, and X. Du, Oxygen vacancies: The origin of n-type conductivity in ZnO, Phys. Rev. B 93, 235305 (2016).

[15]K.I. Hagemark and P.E. Toren, Determination of excess $\mathrm{Zn}$ in $\mathrm{ZnO}$. The phase boundary $\mathrm{ZnZn}_{1+x} \mathrm{O}$, J. Electrochem. Soc. 122, 992 (1975).

[16] L.E. Halliburton, N.C. Giles, N.Y. Garces, M. Luo, C. Xu, L. Bai, and L.A. Boatner, Production of native donors in $\mathrm{ZnO}$ by annealing at high temperature in Zn vapor, Appl. Phys. Lett. 87, 172108 (2005).

[17]L.S. Vlasenko and G.D. Watkins, Optical detection of electron paramagnetic resonance in roomtemperature electron-irradiated $\mathrm{ZnO}$, Phys. Rev. B 71, 125210 (2005).

[18]F. Tuomisto, K. Saarinen, K. Grasza, and A. Mycielski, Observation of $\mathrm{Zn}$ vacancies in $\mathrm{ZnO}$ grown by chemical vapor transport, Phys. Status Solidi B 243, 794 (2006).

[19]A. Janotti and C.G. Van de Walle, Oxygen vacancies in ZnO, Appl. Phys. Lett. 87, 122102 (2005). 
[20]A. Tsukazaki, A. Ohtomo, and M. Kawasaki, High-mobility electronic transport in $\mathrm{ZnO}$ thin films, Appl. Phys. Lett. 88, 152106 (2006).

[21]Y. Liu, V. Avrutin, N. Izyumskaya, Ü. Özgür, A.B. Yankovich, A.V. Kvit, P.M. Voyles, and H. Morkoç, Electron scattering mechanisms in GZO films grown on a-sapphire substrates by plasma-enhanced molecular beam epitaxy, J. Appl. Phys. 111, 103713 (2012).

[22]W.A. Hadi, M.S. Shur, and S.K. O'Leary, The sensitivity of the steady-state and transient electron transport within bulk wurtzite zinc oxide to variations in the crystal temperature, the doping concentration, and the non-parabolicity coefficient, J. Mater. Sci. Mater. Electron. 24, 2 (2013).

[23]E. Furno, F. Bertazzi, M. Goano, G. Ghione, and E. Bellotti, Hydrodynamic transport parameters of wurtzite $\mathrm{ZnO}$ from analytic- and full-band Monte Carlo simulation, Solid State Electron. 52, 1796 (2008).

[24]W.A. Hadi, M.S. Shur, and S.K. O'Leary, A transient electron transport analysis of bulk wurtzite zinc oxide, J. Appl. Phys. 112, 033720 (2012).

[25]S. Sasa, T. Maitani, Y. Furuya, T. Amano, K. Koike, $M$. Yano, and M. Inoue, Microwave performance of $\mathrm{ZnO} / \mathrm{ZnMgO}$ heterostructure field effect transistors, Phys. Status Solidi A 208, 449 (2011).

[26]L. Ardaravičius, O. Kiprijanovič, J. Liberis, M. Ramonas, E. Šermukšnis, A. Matulionis, M. Topor- kov, V. Avrutin, Ü. Özgür, and H. Morkoç, Highfield electron transport in doped $\mathrm{ZnO}$, Mater. Res. Express 4, 066301 (2017).

[27]L. Ardaravičius, O. Kiprijanovič, M. Ramonas, E. Šermukšnis, J. Liberis, A. Šimukovič, A. Matulionis, K. Ding, Md.B. Ullah, V. Avrutin, Ü. Özgür, and $\mathrm{H}$. Morkoç, Electron drift velocity in wurtzite $\mathrm{ZnO}$ at high electric fields: experiment and simulation, J. Appl. Phys. 126, 185703 (2019).

[28]M. Ramonas and C. Jungemann, A deterministic approach to noise in a non-equilibrium electronphonon system based on the Boltzmann equation, J. Comput. Electron. 14, 43 (2015).

[29]L. Ardaravičius, M. Ramonas, J. Liberis, O. Kiprijanovič, A. Matulionis, J. Xie, M. Wu, J. H. Leach, and $\mathrm{H}$. Morkoç, Electron drift velocity in latticematched AlInN/AlN/GaN channel at high electric fields, J. Appl. Phys. 106, 073708 (2009).

[30]L. Ardaravičius, O. Kiprijanovič, J. Liberis, A. Matulionis, E. Šermukšnis, R.A. Ferreyra, V. Avrutin, Ü. Özgür, and H. Morkoç, Threshold field for soft damage and electron drift velocity in InGaN twodimensional channels, Semicond. Sci. Technol. 30, 105016 (2015).

[31]L. Ardaravičius, A. Matulionis, J. Liberis, O. Kiprijanovič, M. Ramonas, L.F. Eastman, J.R. Shealy, and A. Vertiatchikh, Electron drift velocity in AlGaN/GaN channel at high electric fields, Appl. Phys. Lett. 83, 4038 (2003).

\title{
İELEKTRINTŲ DEFEKTŲ TANKIO İVERTINIMAS NAUDOJANT KARŠTŲJŲ ELEKTRONŲ PERNAŠOS TYRIMUS EPITAKSINIAME ZnO
}

\author{
L. Ardaravičius, O. Kiprijanovič, M. Ramonas, E. Šermukšnis, A. Šimukovič, A. Matulionis
}

Fiziniu ir technologijos moksly centras, Vilnius, Lietuva

\section{Santrauka}

Naudojant nanosekundinių ịtampos impulsų matavimo metodiką ištirta karštųjų elektronų pernaša kambario temperatūroje nominaliai nelegiruotuose $\mathrm{ZnO}$ epitaksiniuose sluoksniuose. Bolcmano kinetinè lygtis išspręsta sferinių harmonikų metodu siekiant atsižvelgti i karštujų elektronų efektus. Naudojant šiuos metodus ivvertintas įelektrintų taškinių defektų tankis (vakansijų $1,6-1,9 \times 10^{17} \mathrm{~cm}^{-3}$ ir sočiujų jungčiu $\left.1,7-2,0 \times 10^{17} \mathrm{~cm}^{-3}\right)$, elektronu dreifo judris silpnuose ir vidutiniuose laukuose bei elektronų tankis. Ivvertintas deguonies vakansijų tankis koreliuoja su $\mathrm{Zn}$ celès auginimo temperatūra. Naudojant trumpus impulsus (3 ns) sumažintas savai- minio pakaitimo efektas ir tirtuose sluoksniuose pasiekiami $430 \pm 50 \mathrm{kV} / \mathrm{cm}$ elektriniai laukai. Išskiriami du elektriniu laukų ruožai, kuriuose srovès priklausomybè nuo elektrinio lauko stiprio gali būti aproksimuota skirtingio polinkio tiesemis. Matuojant srovès laiką aiškejja, kad elektronų tankis yra pastovus, kai elektrinio lauko impulsas siekia iki $320 \mathrm{kV} / \mathrm{cm}$. Nuokrypis nuo Omo dèsnio aiškinamas karštujų elektronų efektais ir elektronų sklaida ịkrautais taškiniais defektais bei fononais. Ivertintas didžiausias elektronų dreifo greitis lygus $\sim 2,9 \times 10^{7} \mathrm{~cm} / \mathrm{s}$, kai elektronu tankis $1,5 \times 10^{17} \mathrm{~cm}^{-3} \mathrm{su}-$ darant $320 \mathrm{kV} / \mathrm{cm}$ stiprio elektrinị lauką. 